\title{
Analysis of the Teaching Mode of Joint Creation of Animation Major in Application-Oriented Universities
}

\author{
Jindong Wang \\ Fujian Jiangxia University, Fuzhou350002 ,China. \\ wjdpm2008@163.com
}

\begin{abstract}
Keywords: Animation; Joint creation; Teaching mode
\end{abstract}
\begin{abstract}
With the development of animation industry and the renewal of new technology and concept, the animation market has put forward new requirements for the training of applied animation talents. Based on the current problems in the cultivation of animation professionals in application-oriented universities, this paper, from the aspects of team building, project formulation, studio improvement, joint tutors, and assessment and evaluation mechanism, provides solutions and countermeasures for the construction of a new practical teaching system for application-oriented undergraduate animation major.
\end{abstract}

\section{Introduction}

In recent years, with the gradual promotion of the construction of application-oriented universities, application-oriented universities all over the country have reformed the training mode of applied talents. In all kinds of teaching reforms, the status and role of the reform of practice teaching mode in the process of cultivating applied talents has been promoted to a new height. The quality of practice teaching has even become an important index to measure the quality of cultivating applied talents in a school or a major. Therefore, the reform and innovation of practical teaching mode in application-oriented universities has become an important topic in the current educational reform of application-oriented universities.

The animation major is a comprehensive practical subject which integrates art and technology. The cultivation of practical ability is the most important part of the cultivation of applied animation talents. Although the current teaching reform of animation major in application-oriented universities has improved the quality of training applied animation talents, the graduates of animation majors still can not meet the job requirements immediately after entering the enterprise, thus affecting the employment rate of graduates. Animation companies are also frustrated by the inability to recruit experienced animation talents. The old problem that animation graduates are disconnected from the industry has not yet been effectively solved.

This paper aims to explore the construction of a practical teaching model with the animation market demand as the guide, cultivation of animation practice ability as the core, project as the main line, students, teachers and enterprise personnel as the team, and campus studio as the practice platform, shorten the distance between school and industry, achieve seamless docking between animation graduates and jobs, train applied animation talents with professional theoretical literacy, innovative thinking and solid practical experience, and try to solve the problem of training applied talents in animation specialty at present[1].

\section{Current Situation of Practical Teaching Reform in Animation Specialty of Application-Oriented Universities}

In recent years, under the guidance of the Ministry of Education's policy on the cultivation of applied talents, application-oriented universities all over the country have deepened the reform of the cultivation model of applied talents, and the status of practical teaching reform has been promoted to a new height. These practical teaching reforms are mainly embodied in two aspects. One is the "project introduction" teaching reform, which introduces the actual project of the enterprise into the process of practical teaching in school. However, in practical application, 
colleges and universities often simply introduce business projects into the subject, and then divide the project into different courses, so that teaching and learning can only complete isolated course tasks and assignments, which ignores the integrity of animation production and the cultivation of teamwork consciousness, and fails to effectively enhance students' professional practice ability[2]. On the other hand, business projects are generally commercial projects. The project acceptance, production and closure are strictly regulated and required. It is difficult to connect the enterprise project with the school teaching plan and the student's completeness in terms of time arrangement and quality requirements. This will inevitably affect the normal progress of the project, difficult to meet market demand, and ultimately make the project practice become a mere formality[3].

The second kind of practice teaching reform is the "studio practice teaching mode", that is the establishment of animation major studios on campus, and the practical training is carried out by school teachers as the practical training instructors[4]. The problem of this practical teaching method is that the studios in colleges and universities are different from the production environment of enterprises, students can not work like company employees, and the efficiency of animation production is not comparable with that of company's production personnel. Moreover, students have insufficient practical experience and uneven professional skills, and project quality cannot be guaranteed. As the enterprise project is to pursue profits, it means that it is impossible to take teaching quality as the goal of the project. Therefore, the animation production mode of enterprises can not be fully implemented in university studios[5].

Through the problems in the above practical teaching reform, it can be seen that the current practical teaching of animation major in application-oriented universities is mostly at the shallow and medium level, and the quality of practical teaching is far from the training goal of applied talents in the real sense. The practice teaching reform of animation major in application-oriented universities is facing many difficulties and constraints. How to find a scientific practice teaching mode in the predicament is a new challenge for animation major in application-oriented universities. The practice teaching method of "joint creation" discussed in this paper is a beneficial attempt to solve the problems existing in the practice teaching of animation specialty[6].

\section{Construction Strategy of “Joint Creation” Teaching Mode for Animation Majors}

"Joint creation" teaching mode is oriented by the development of animation industry, with professional projects as the main line and studio as the platform. Through the students of different grades in the joint animation major, on-campus tutors and production personnel of the company, the joint creation team and the joint mentor team are formed. It can construct project-oriented curriculum, practice-oriented teaching and product-oriented graduation design to achieve the teaching objectives of integrating curriculum and project, project and post, and creation and industry. It can also achieve connection and interaction between students and students of different grades, between students and teachers, between teachers and enterprise personnel, and between universities and industries, and take the cultivation of students' practical ability and teamwork ability as the core[1].

Setting up "Joint Creation" Project Team. The selection of the members of the "joint creation" team is centered on the outstanding students, breaking the barriers of specialty, grade and class, changing the singleness of the student source structure, and establishing the project team according to the production process of the animation enterprise and the students' specialty and interest, including optional animation director, the division of labor, the formulation of work rules and regulations, animation production standard, production cycle, process plan, detailed rules and regulations of project assessment, etc. In the arrangement of work posts, students need to be grouped by tests to teach students in accordance with their aptitude, so that students can clearly define the nature and requirements of their positions before entering the team, and give full play to students' personality and characteristics.

Making the Project Scheme and Plan of "Joint Creation". The introduction of "joint creation" teaching model project must break through the original single project type. In addition to the actual business projects of enterprises, professional competition events, teacher research 
projects and independent research and development projects should also be actively introduced. Due to the particularity of the student team and various constraints of commercial projects, it is not appropriate to introduce too many commercial projects, and more independent projects should be introduced which meet the actual ability of students and the actual conditions of the school. Teachers, business personnel and student teams will discuss and work out the project plan according to the requirements of the syllabus and personal interests. However, independent projects are required to be practical and have marketing potential. In the process of making the plan, the students can adjust the practical plan according to the specific situation in time, so that the students can really understand the way and method of solving the actual project problems, and enhance the purpose of students' autonomous learning[7]. Through the actual exercise of the project and the improvement of teachers and students' practical ability and team awareness, the practical teaching quality of animation major is improved constantly[3].

It is very important to make a detailed work schedule after making a creative project plan. This requires the student team leader to communicate and negotiate with the team members, select suitable positions according to each students' specialty and interest, and customize detailed workload, quality requirements and completion time according to the work schedules of different post requirements[8].

Cultivating Team Spirit and Communication Skills. Animation is a comprehensive subject, and its creation is also a process of team cooperation and a cooperative art. Therefore, in the practice teaching reform, it is very important to cultivate students' team consciousness and communication ability. Without team spirit, it is impossible for everyone to create excellent works by calculating personal gains and losses and preferences and not obeying team arrangements. Through the "joint creation" team, which provides students with the space for teamwork, students can communicate with each other in the creation process, so that students can learn to cultivate the team awareness of working towards common goals regardless of personal gains and losses in the creation process, so as to give full play to the advantage of team creation.

In the process of joint creation, there are always difficulties. Especially in the early stage of animation creation, members lack cooperation experience and have not yet established cohesion. Any carelessness will cause differences and opinions among members, which will discourage members' initiative in creation and learning and even bring the whole project to a halt[8]. At this time, communication is the only way to solve the problem. Teachers should make use of various teaching activities according to the actual situation, so that students and teachers can establish an atmosphere of active and extensive discussion and communication, so that team members can understand that they are interdependent, and establish the team concept of mutual trust and mutual benefit when completing creative tasks[9].

Optimizing the Studio System Practice Teaching Platform on Campus. "Joint creation" studio is a practical teaching platform with industry development as the guide, students' practical ability as the core, projects as the main line, and students independently complete projects under the guidance of school-enterprise joint mentor[10]. "Joint creation" studio is not the traditional studio "training classroom" concept, but a new and open platform for teachers and students to create and exchange, so that students in the studio have more autonomous space for creative learning, especially the exchange of experience among students of different grades, which is helpful to improve students' enthusiasm for independent learning. The creation of this kind of exchange atmosphere can not only enhance students' practical ability but also cultivate students' team consciousness[11].

Studios adopt a teaching system simulating enterprise management, establish a perfect studio management system, practice project development system, and work publicity and promotion system, implement project-oriented teaching content, enterprise-oriented teaching environment, diversified teaching evaluation, and product-oriented practical creation, and achieve the integration of teaching objectives and post objectives, the combination of creative process and enterprise production process, and the consistency between creative environment and enterprise environment. This open practice teaching mode weakens the thinking of "classroom" and "curriculum", closes the 
distance between teachers and students, and between schools and enterprises, naturally links up the studio practice teaching and animation market demand, strengthens the cultivation of students' practical ability, and fully excavates the initiative and innovation of students' learning[12].

Establishing "Joint Creation" Teaching Team. Colleges and universities require highly educated teachers, so the lack of practical ability of animation majors in colleges and universities has been a problem that can not be solved in a short time. And the enterprise personnel with many years of industry experience can not enter the university because of education background and other reasons. In order to solve this contradiction, the teaching mode of "joint creation" introduces enterprise designers with rich creative experience to form a joint tutorial team with university teachers. On the one hand, it guides students' practice, and on the other hand, through the interaction and communication with enterprise personnel, the practical ability of university teachers is enhanced, the practical teaching level of university teachers is improved, and at the same time, it is conducive to the construction of a double-qualified university teacher team[11].

"Joint creation" team changes the traditional preach teaching method in the teaching mode, and adopts the joint creation of teachers and students. The tutor is both a teacher and a student, teaching and learning. The advantages of communication in this teaching mode should be brought into full play to realize both teaching and learning. In addition, in order to give full play to the initiative of students to learn, teachers and students can form teams freely, and teachers and students can work together to complete the project creation[9]. The "joint creation" tutorial team breaks through the traditional spoon feeding teaching mode of "one to many" and "just moving mouth and doing nothing", and realizes the organic integration of students, teachers and enterprise personnel. Finally, a practical teaching tutor team will be formed, including the mutual promotion between theory and practice, between academic qualifications and skills, and between schools and industries[1].

Formulating a Diversified Assessment System. The "joint creation" practice teaching belongs to the practice teaching on campus, so the studio practice teaching platform can not fully meet the production environment and management mechanism in the enterprise. Even if the industry management mechanism and assessment criteria are completely adopted, the students can not adapt to the strict management and assessment mechanism under the enterprise mode. Therefore, in the joint creative training, it is necessary to formulate a assessment and evaluation system for students to gradually adapt to the transition from school teaching mode to enterprise management mode.

Therefore, the "joint creation" teaching mode adopts more diversified assessment and evaluation system, adopts diversified assessment standards according to the different performance of students in different positions, and combines the evaluation standards of colleges and universities with the requirements of the actual commercial project to build a diversified evaluation system. In addition to the traditional teacher's evaluation on the completion degree, visual effect and technical content of the work itself, the enthusiasm, efficiency, coordination and communication ability of the students in the creation, as well as the students' mutual evaluation of the group members are also included in the evaluation system. At the same time, the evaluation made by the enterprise tutor to the students from the professional post standards will also be included in the evaluation system. Through the integration of these three evaluation standards, an objective and diversified evaluation system will eventually be formed.

\section{The Practical Significance of "Joint Creation" Teaching}

With the rapid development of animation industry, the animation market has constantly improved the new skills and requirements of animation talents. These changes have put forward new requirements for the training of applied talents of animation major[1]. This requires animation teaching in colleges and universities not only to cultivate students' professional practice ability, but also to cultivate students' innovative thinking, communication ability, and teamwork ability[5]. Under the background of the development of this industry, the teaching mode of joint creation is to improve the practice teaching quality of animation major with the new idea of joint creation teaching between teachers and students.

Firstly, the joint creative teaching mode creatively integrates students, teachers and enterprise 
personnel to form a joint creative team. This creative teaching team takes students as the main body, breaks the traditional teaching method of teacher's preach, and creates an open, equal and mutually beneficial teaching environment, which not only protects the students' personality development, but also strengthens the requirements of the industry post standard. At the same time, the joint team of enterprise personnel and university teachers can not only complement each other's advantages and help university teachers to improve their practical ability, but also benefit the construction of the "double-qualified" teaching team in colleges and universities to improve their knowledge application ability, practical innovation ability and social service ability[4]. Secondly, the diversified practice projects are more suitable for students' abilities and conditions than the previous single practice projects, so that students of different grades and different professional abilities can participate in the creation, so that they can independently choose skilled positions according to their own specialties and hobbies, which further improves students' learning initiative. Finally, the most fundamental reform of the joint creative teaching mode lies in the full communication and mutual cooperation between students, teachers and students, universities and enterprises. It optimizes the current single practical teaching mode for applied undergraduates, greatly improves the quality of practical teaching for animation majors, and effectively promotes the integration of education and industry, which has a positive and far-reaching significance to improve the training of innovative and applied talents in animation specialty[9].

\section{Acknowledgement}

Fund project: Educational Research Projects for Young and Middle-Aged Teachers in Fujian; Project number: JAS170547.

\section{References}

[1] Juanjuan Chen: Analysis on the Necessity of "Project Driven" Talent Training Mode Reform in Animation Specialty, Art Education Research, 2018(10): 110.

[2] Qing Yong, Lei Li and Xuelian Tang: Construction of Animation Speciality Teaching System Based on Studio Practice Platform, New Technology and Products of China, 2011(6): 104.

[3] De Lan: Study on the Practical Teaching Problems of "Project Promotion" Integration of Production and Teaching in Animation Speciality, Journal of Changchun Normal University, 2018(3): 180 .

[4] Changpo Fan and Hai Yi: Exploration of Studio System Practice Teaching Mode in Animation Speciality, 2012(11): 154-156.

[5] Chongyao Zhong and Sixiao Ren: A Study on the Optimization of Practical Creative Courses in Animation Teaching -- Taking the Animated Movie Nanjing as an Example, Art \& Design, 2018(3): 140.

[6] Jinming Li: Research on Teaching Method Innovation of "Promoting Teaching by Competition" in Animation Specialty, Art Science and Technology, 2017(12): 376.

[7] Hong Yu: Research on Teaching System of Comprehensive Practice Course for Animation Major, Journal of Yangtze Normal University, 2012(6):66.

[8] Liang Wei: Team Cooperative Spirit in Animation Teaching, Art Panorama, 2013(2):143.

[9] Jianjun Chen: Research on the Construction of Cross Border Joint Teaching Mode in Colleges and Universities in the "Micro Era" -- Taking Animation Short Films as an Example, Contemporary Cinema, 2016(11): 174-176.

[10] Wuying Deng: The Basis, Indicators and Methods of Quality Evaluation of "Studio System" Teaching Model-Taking the Animation Specialty of Changsha University as an Example, Art Panorama, 2012(12):173.

[11] Pei Ge: Research on the Operation Mode of "Mentoring" Studio for Animation Majors, Journal of Changzhou Vocational College of Information, 2015(4):45.

[12] Jinling Dai: Exploration and Practice of "Linkage Type" Teaching Mode -- Taking animation studio of Dalian Art College as an example, Art Panorama, 2013(6):155. 